\title{
TRAPPC10 wt Allele
}

National Cancer Institute

\section{Source}

National Cancer Institute. TRAPPC10 wt Allele. NCI Thesaurus. Code C75427.

Human TRAPPC10 wild-type allele is located in the vicinity of $21 \mathrm{q} 22.3$ and is approximately $94 \mathrm{~kb}$ in length. This allele, which encodes trafficking protein particle complex subunit 10 protein, may play a role in transport of vesicles from endoplasmic reticulum to Golgi. Mutations in this gene are associated with holoprosencephaly 1. 